\title{
The Inspiration of Umbul Binangun Taman Sari on Interior Design of Hotel Tentrem Yogyakarta Lobby
}

\author{
Yossevani Sarah Sanjaya ${ }^{1 *}$ Noeratri Andanwerti ${ }^{1}$ Silvia Meliana ${ }^{2}$ \\ ${ }^{1}$ Interior Design Department, Faculty of Art and Design, Tarumanagara University, Jakarta 11440, Indonesia \\ ${ }^{2}$ Interior Design Department, School of Design, Bina Nusantara University, Jakarta 11480, Indonesia \\ "Corresponding author. Email: yossevani.615170030@stu.untar.ac.id
}

\begin{abstract}
Hotel Tentrem is a city hotel or 5-star business hotel in Yogyakarta with a vision and mission to preserve, develop and introduce the culture, traditions and beauty of Indonesia to the world with Indonesian hospitality. This study focuses on interior design that applies local elements of Yogyakarta, which is inspired by Umbul Binangun Taman Sari, a historic building in Yogyakarta, which used to be the place for Sultan of Yogyakarta and his family to rest. This research focuses on the main room and facilities of Hotel Tentrem, namely the lobby area. The aim of this study is to represent the application of the characters of Umbul Binangun area to the design interior of a contemporary style hotel. The design uses the transformation method with the design method consisting of 3 main stages, which are the programming stage, the concept stage, and the design development stage by considering several things such as location, hotel and company's history, vision and mission, organizational structure, facilities, philosophy and also characters of Hotel Tentrem as well as Taman Sari Umbul Binangun. The result of this study is that Inspiration of Umbul Binangun Taman Sari is applied to the lobby of Hotel Tentrem Yogyakarta by applying natural elements to the floor, wall, ceiling, and furniture, such as the use of natural stone, wood, metal and aesthetic elements in the form of native Indonesian plants. Umbul Binangun Taman Sari's ambience is also supported by the use of materials that resemble the element of water both in terms of texture and visual. In conclusion, the inspiration of a historic building, Taman Sari, is applied to the design through the interior elements.
\end{abstract}

\section{Keywords: Binangun, Design, Hotel, Interior, Umbul}

\section{INTRODUCTION}

Yogyakarta is a city with great economic potential in tourism. The success of Yogyakarta can be seen clearly from the increase in income of the population, especially the handicraft sector, small industries (batik, leather, and wood), and trading as a result of the influence of the development of Yogyakarta as the second tourist destination (Daerah Tujuan Wisata) after Bali [1]. Yogyakarta often holds both local and international business and trade activities. Therefore, businessmen and tourists who come from outside the town and abroad need hotel as a place to do their business' meetings, and also to rest.

According to Surat Keputusan Menteri Pariwisata, Pos, dan Telekomunikasi no.KM37/PW.340/MPPT-86 [2], regarding the requirements for hotel management businesses, a hotel is an accommodation that uses some parts or all of building's parts that provides lodging services in the form of rooms for rent, food and beverages and other facilities for public that are managed commercially.

Referring to Marlina in her book Design Guide for Commercial Buildings [3], a business hotel is a hotel that is designed to accommodate guests and has business goals. As the name implies, doing business in a certain area is the main market for business hotels. business hotel is also known as City Hotel.

Hotel Tentrem Yogyakarta is a 5-star city hotel in Yogyakarta. Located in a strategic location and easily accessible from outside and within the city, this hotel is suitable for guests with business and leisure purposes.

Hotel Tentrem Yogyakarta is one of the five-star local hotels in Yogyakarta with a vision and mission to preserve, develop and introduce the culture, traditions, and beauty of Indonesia to the world with Indonesian hospitality [4]. From its name, this hotel embraces the concept of harmony between the universe and humans to create ideal spiritual conditions, so that all people live in peace, hoping that whoever comes or stays at this hotel will feel serenity or peace of mind. The concept of harmony between the universe and humans to create tranquility and peace of mind is the reminiscent of Taman Sari, a historic building in Yogyakarta that used to be the place for the hospitality activities of the Ngayogyakarta Hadiningrat Palace family. According to Rina Kurniati [5], Taman Sari has two nicknames. The first nickname is Water Castle because a long time ago, this palace was surrounded by water and had a function as a place for bathing and relaxing for the royal 
family. Besides that, Taman Sari is also dubbed as the Fragrant Garden because it has a beautiful garden and various plants.

The Taman Sari building is divided into several parts; the most famous one is Umbul Pasiraman, the private bathing place of the Sultan, his wives (including concubines), and his sons and daughters [6]. Umbul Pasiraman consists of 3 large pools, namely Umbul Muncar, Blumbang Kuras, and Umbul Binangun, which are the private pools of the Sultan and his empress [6]. Umbul Binangun is more exclusive and personal because it is separated by a tower building, which is Sultan's resting place. The area of Umbul Binangun is decorated with decorations of mushroom springs (circles) with large plant pots arranged around the pond to enhance the beauty.

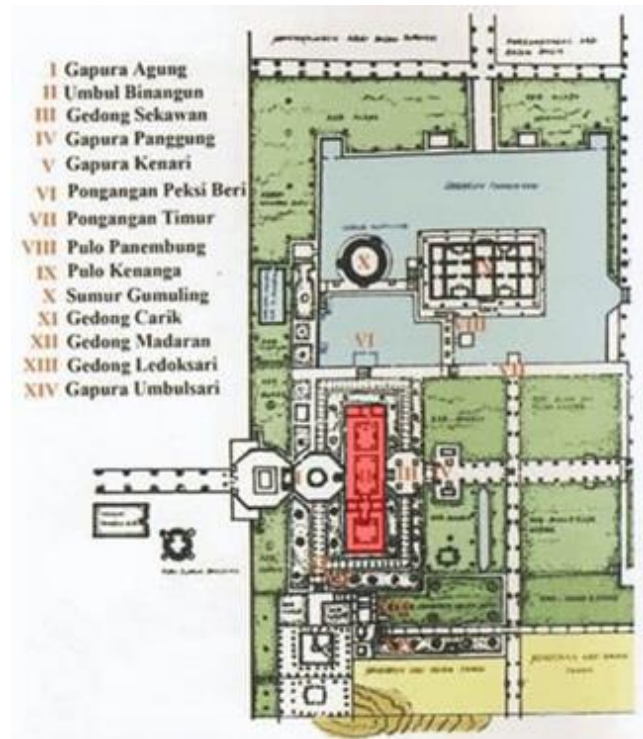

Figure 1 Plan of Pesanggrahan Taman Sari Source: www.indonesianholic.com [7]

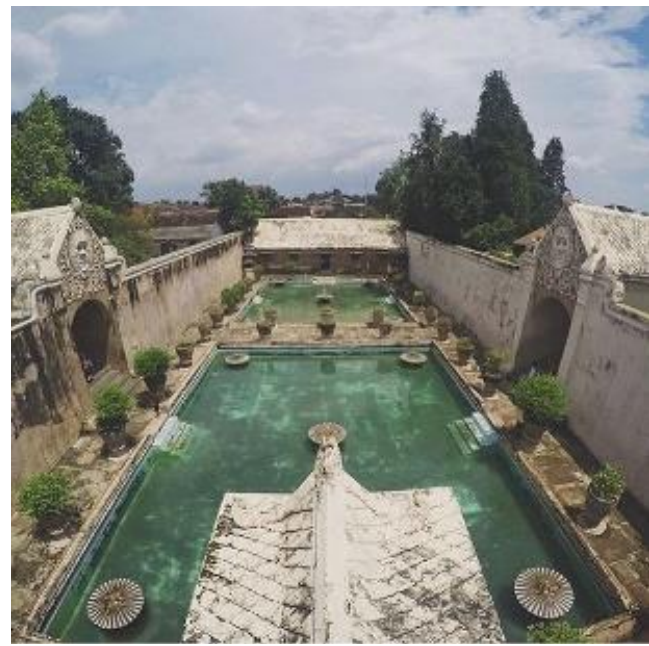

Figure 2 Umbul Muncar and Blumbang Kuras Source: www.allindonesiatourism.com [8]
The purpose of this study is to describe the application of Umbul Binangun's elements in the elements of space (floor, wall, and ceiling), space-filling elements (furniture), and artwork in the lobby of Hotel Tentrem Yogyakarta.

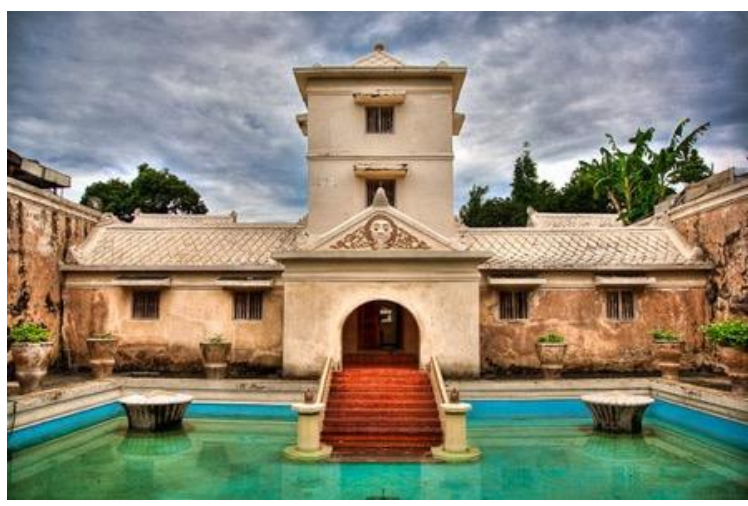

Figure 3 Umbul Binangun

Source: www.allindonesiatourism.com [8]

\section{BACKGROUND}

\subsection{Lobby}

The lobby is a large permanent place centered on the reception and public facilities [9]. The lobby of a hotel is the first place to be seen and becomes the center of all activities in the hotel, so in designing the interior of the lobby, it is essential to consider the forming and filling elements of space such as wall, floor, ceiling, furniture and artwork to give a good impression and reflect the image of the hotel.

In the scope of interior design, what is meant by the elements that make up the space are floor, wall, and ceiling [10]. Besides that, furniture fills the room and artwork to enhance the room's aesthetics. The selection of suitable materials for interior elements can form the desired space ambience, giving a positive image, comfort, safety, and an unforgettable impression for the guests.

Apart from that, there are also elements of furniture. The choice of furniture, material, and shape extremely affect the hotel lobby's image and ambience and also the visitors' comfort and impression. In the lobby, the role of furniture as a filling space is significant because furniture can also create an ambience in the room [11]. The hotel lobby's furniture elements include the receptionist table, sofa, armchair, and coffee table. Many 5-star hotels use custom made furniture with suitable materials to represent the image of the hotel.

\subsection{Floor}

Floor is the basis of space and plays a vital role as a foundation for placing various objects such as furniture and supporting all activities carried out on it so that the lobby floor must be made of strong and safe materials. The floor must also keep the lobby's function as the center of hotel activity and focal point by using materials that represent the 
hotel's image and class. Floors in hotel's lobbies usually use non-slippery marble and terrazzo materials, decorative floors, finite stones, carpets, and composite floor [9].

\subsection{Wall}

Wall is a vertical plane that has the functions to separate and form the space and also support the ceiling, so the hotel lobby walls must be made of strong material. The walls in the hotel lobby also emphasize decorative elements to reflect the hotel's image better. The walls in the lobby should be easy to maintain. The materials used for the walls can be laminated wood, plastic, iron, and glass [9].

\subsection{Ceiling}

Ceiling is part of the elements that make up the space. The ceiling can be interpreted as a barrier between the upper room (roof) and the lower room [12]. The primary function of the ceiling in a design is to cover the upper space. It has the functions for air regulation or heat ventilation [13]. According to Iskandar [14], along with the times, the ceiling also has other functions, for example, as a "point of interest" by making the ceiling height vary according to the room. Some parts can be made higher than other parts (up ceiling) or lower than other parts (down ceiling).

\section{METHODS}

The purpose of this study is to describe the application of Umbul Binangun's elements in the elements of space (floor, wall, and ceiling), space-filling elements (furniture), and artwork in the lobby of Hotel Tentrem Yogyakarta. This study uses Tentrem Hotel lobby area as the object of research.

The purpose of designing the lobby interior of Tentrem Hotel is to create a room that can provide serenity and tranquility for guests by bringing beautiful and luxurious ambience of Umbul Binangun into today's hotel interiors, so that guests can feel the harmonious relationship between humans and nature. Besides, this design also aims to make guests feel comfortable doing their activities, be it business activities or just relaxing and taking a break from their routine. This design applies local Yogyakarta content to its interior, inspired by the historic Taman Sari building combined with natural, luxurious, and elegant elements. Hotel Tentrem can further introduce and preserve Indonesian culture in the midst of today's modern times.

The elements or characters of Taman Sari are applied to the interior of a contemporary style hotel through the transformation design method, which is the method of design with the adjustment of design solution's specification that can be a better guide, in both traditional and contemporary ways, for various design activities and multidisciplinary response [15]. According to Laseau, 1980 as cited in Safitri "Transformasi Arsitektur Monumen Batas Kota dalam Perancangan Mixed-Use Building sebagai Gateway Kota Yogyakarta Bagian Barat di Kawasan Gamping" [16], transformation is categorized into 4 parts:
1. Transformation is Topological (geometric), the geometric shape changes with the same forming component and spatial function.

2. Transformation is Ornamental, performed by shifting, rotating, reflecting, overturning, folding, etc.

3. Transformation is Reversal, where the imagery reversal of the object figure will be transformed, in which the object's imagery is transformed into the reversed imagery.

4. Transformation is Distortion (confusing), which is the freedom of the designers in doing their activities.

This research applies three stages in the design method: the programming stage, the concept stage, and the design development stage. The design method needs to be understood to formulate a conceptual approach in the interior design process. These methods are considered concept catalysts, where some of the design approach methods include pragmatic, typological, analogical, syntactic, programmatic, ideological, and substantive approaches are used in the interior design process.

Furthermore, through the programmatic approach method, the design process is carried out based on a set of rules and programs. In this case, the resulting design is materialquantitative, and the accuracy of problem-solving will be measured through the suitability of the physical form of the design with a predetermined program [17]. The needs analysis is carried out in the programmatic concept, which includes a series of interrelated data/information, namely actors, activities, space requirements, space demands, and forms of space.

Furthermore, in the design concept, it is explained that the design concept is an abstraction that becomes the basis or guide to be translated into a technical level, namely the application of concept abstraction into tangible manifestations that can be measured and depicted visually [17]. If the selection of an appropriate design approach method is done properly and systematically, it will lead the designer to the right design concept to tie the design results into a fully integrated design.

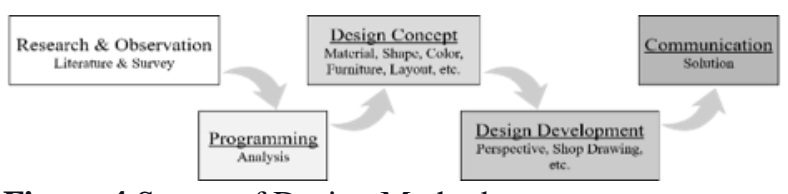

Figure 4 Stages of Design Method

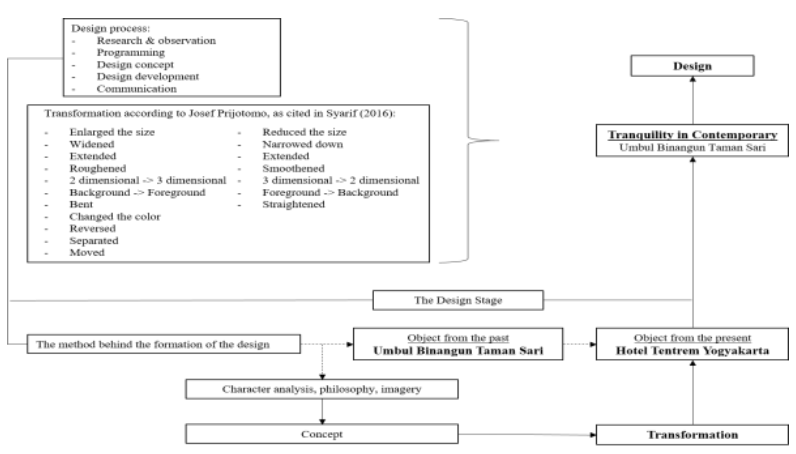

Figure 5 Flow of Design Thinking [18] 


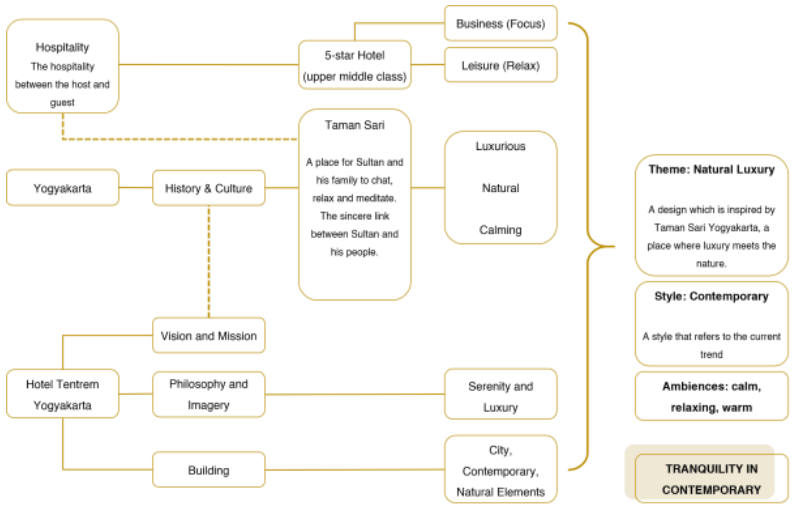

Figure 6 Design Concept
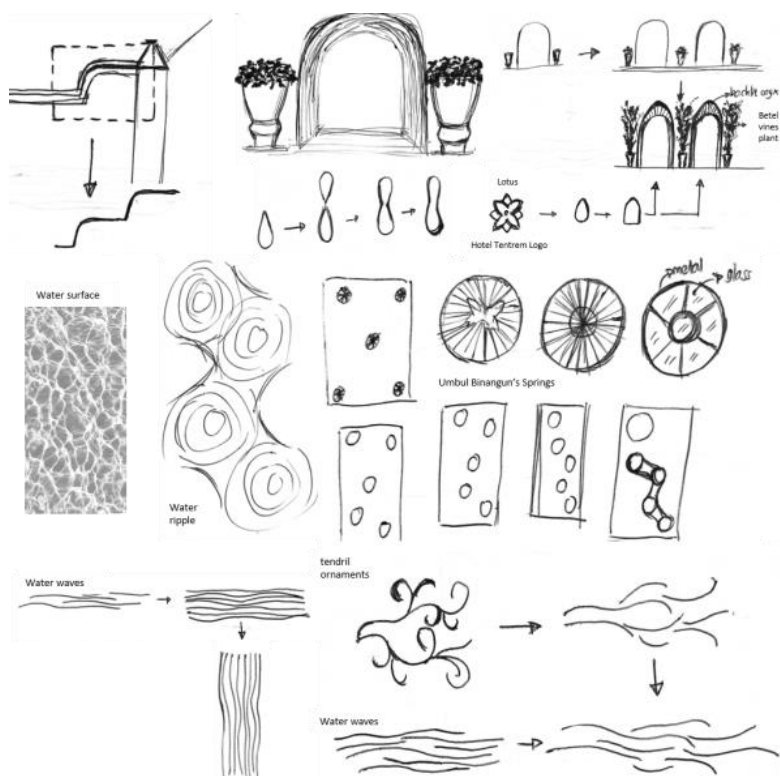

Figure 7 Transformation Design

\section{RESULTS AND DISCUSSION}

This design takes the local elements of content from one of the historic buildings in Yogyakarta, which used to be a hospitality facility for the royal family, namely Taman Sari, more specifically, it takes the inspiration from the Umbul Binangun area.

The lobby as the main area and is first to be encountered by the guests must have a distinctive and strong appeal, yet still reflects the hotel as well as the local cultures. The hotel lobby is an area with various functions, for instance, it can be the place to meet with fellow business partners, or the place to wait or rest for a while. Therefore, the lobby area requires a calm, relaxing and warm ambience to support all those activities. Umbul Binangun is one of the distinctive areas and becomes the icon of Taman Sari, because it is still dominated with water elements and extremely reflects Taman Sari, which is known as the Water Castle. Umbul Binangun extremely reflects the image of calmness, serenity and relaxation with the natural elements within it, this is in line with the ambience which is aimed to be created at the lobby. The design statement is "Tranquility in
Contemporary", in which the serenity of the image of Hotel Tentrem and Taman Sari blends in with the current trend. The contemporary elements in this design can be seen in the layout, furnitures' layout, and also the selection of materials, shapes as well as colors of the interior elements. The inspiration from Umbul Binangun is applied to various interior elements of the Hotel Tentrem Yogyakarta lobby, including the elements that make up the space (floor, wall, ceiling) and elements of space-filling (furniture and artwork).

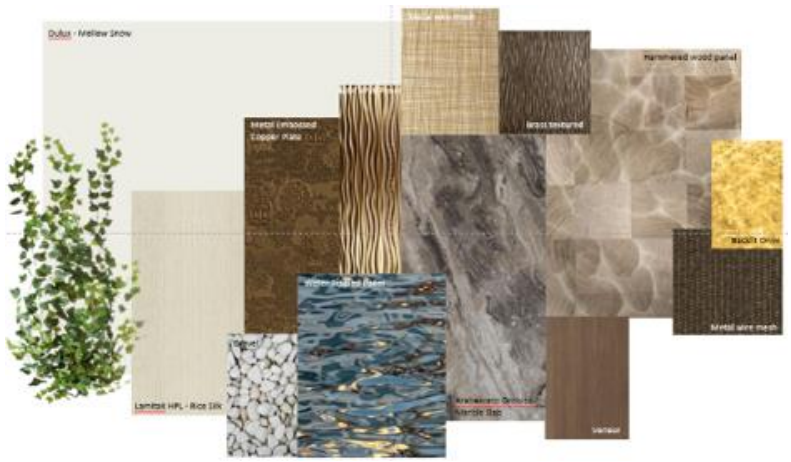

Figure 8 Material and Color Schemes

\subsection{Floor}

The lobby area's design, especially in the waiting area, wants to create an experience as if the guests are in Umbul Binangun Taman Sari. The floor in the waiting area uses glass flooring with laminated glass material in several parts, located according to guests and staff's circulation to remain safe and do not interfere. At the bottom of this glass flooring, there is a floor surface with a water rippled panel as a cover to provide visuals such as reflections of the water surface. This unique floor design brings water elements from Umbul Binangun to the lobby's interior while delivers a memorable experience for guests.

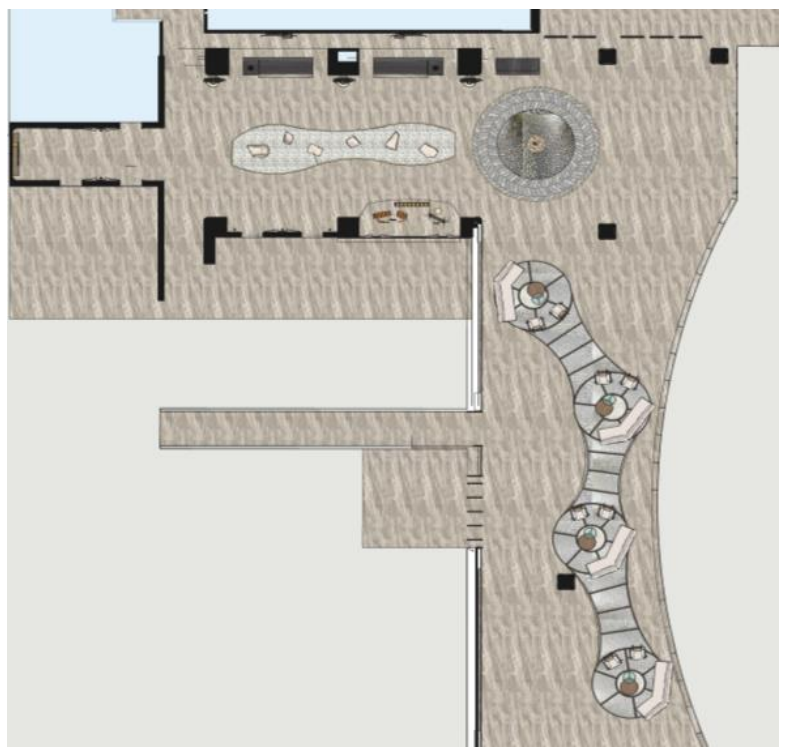

Figure 9 Lobby Floor Plan 
In terms of aesthetics, the combination of laminated glass and water rippled panels used on some floors of the lobby gives a soothing impression because of its water-like visuals. In addition, the water element that is brought into the interior combined with the circle pattern of the glass floor gives a unique experience that reminds of Umbul Binangun.

From the functional perspective, the laminated glass is a strong type of glass and is commonly used for flooring materials. Beside being easy to clean, this glass material also has a pretty good acoustic function. An anti-slip coating can be used for indoor users' safety so that the glass surface is not too slippery.

Hotel Tentrem Yogyakarta's lobby floor predominantly uses marble slab polished, Arabescato Orobico type, with a dark gray base color and light gray on the veins.

In terms of aesthetics, the usage of marble on the entire lobby floor creates a luxurious, elegant, and expensive impression. Its smooth surface with clear and unidirectional marble veins gives a broad and visual image like water flow. From the functional perspective, marble is a thick and rigid material, so it is strong and durable when used as the floor. The smooth marble surface has been coated with a coating and makes it easier to maintain and is resistant to scratches. Also, marble has a cool nature or does not conduct heat, so that the marble floor will not expand and even crack when exposed to hot temperatures or sunlight, and can provide coolness to the room.

In addition, there is an elevation in several parts of the lobby floor, such as in the sitting area in front of the reception, which uses a floor drop and is covered with small natural rock material (gravel). Aesthetically, these stones give the impression of a natural lobby interior and are close to nature. Functionally, these small stones effectively serve as an acoustic element.

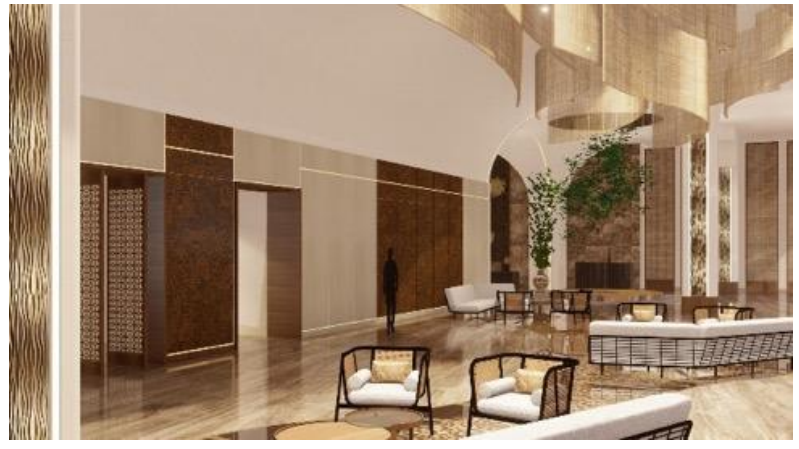

Figure 10 Lobby Waiting Area

\subsection{Wall}

The outer wall uses frameless glass material, allowing lots of natural light to enter to illuminate the room during the day. The reception area walls use hammered wood panel material, which is carved wood panels so that the surface is textured and has a motif like the surface of the water. While the walls in the waiting area use plywood with broken white HPL finishing and metal embossed copper plate with dark bronze color. The columns in the lobby area use MDF wall panel finishing with wave texture.

In terms of aesthetics, the combination of various types of materials with neutral colors that come from nature, such as brown, beige, white, and gray with gold accents, gives an elegant and luxurious impression to the lobby. The white color and textures that resemble the surface or flow of water are inspired by Umbul Binangun as a water castle with many elements or water elements.

From the functional perspective, processed wood and HPL materials have strong and stable properties and are easy to maintain. Apart from that, wood is also an excellent acoustic material.

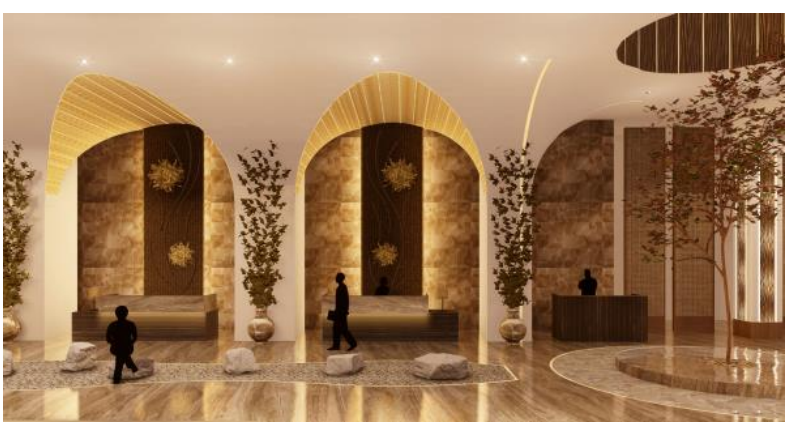

Figure 11 Receptionist Lobby

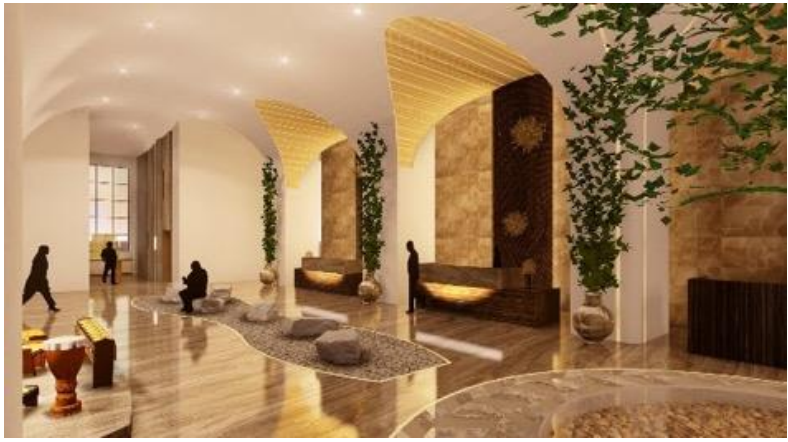

Figure 12 Receptionist Lobby

\subsection{Ceiling}

The lobby area of Hotel Tentrem Yogyakarta applies a ceiling design with voids. Rooms with voids have many advantages, including improving air circulation and allowing lots of sunlight to enter. With the void, the ceiling is high enough, which is on the second floor.

The ceiling shape takes inspiration from the architectural form of Taman Sari, which is built by a Portuguese architect with a colonial building style. The distinctive feature of this building is that it uses curved or dome shapes. The ceiling uses a dome construction with curved shapes covered with gypsum material for finishing wall paint. At the same time, the top in the reception area uses a backlit onyx panel with a gold color that reflects the image of Hotel Tentrem, so that guests who come can easily find the receptionist. The waiting area ceiling uses metal wire mesh to form a water flow pattern adjusting to the lobby circulation. Beside 
functioning as the decoration, metal wire mesh can also serve as an excellent acoustic material.

In terms of aesthetics, the white color used on the entire ceiling gives a clean and spacious impression. Its high location makes the lobby feel more spacious. The use of backlit onyx in the reception area makes it as the focal point. From the functional point of view, gypsum as a ceiling makes it easier to treat and avoid termites. Metal wire mesh that is arranged to resemble water flow on the roof serves as a guide for guest circulation. The different types of ceilings make the division of the area in the lobby clear. Besides, the material used has an excellent acoustic function.

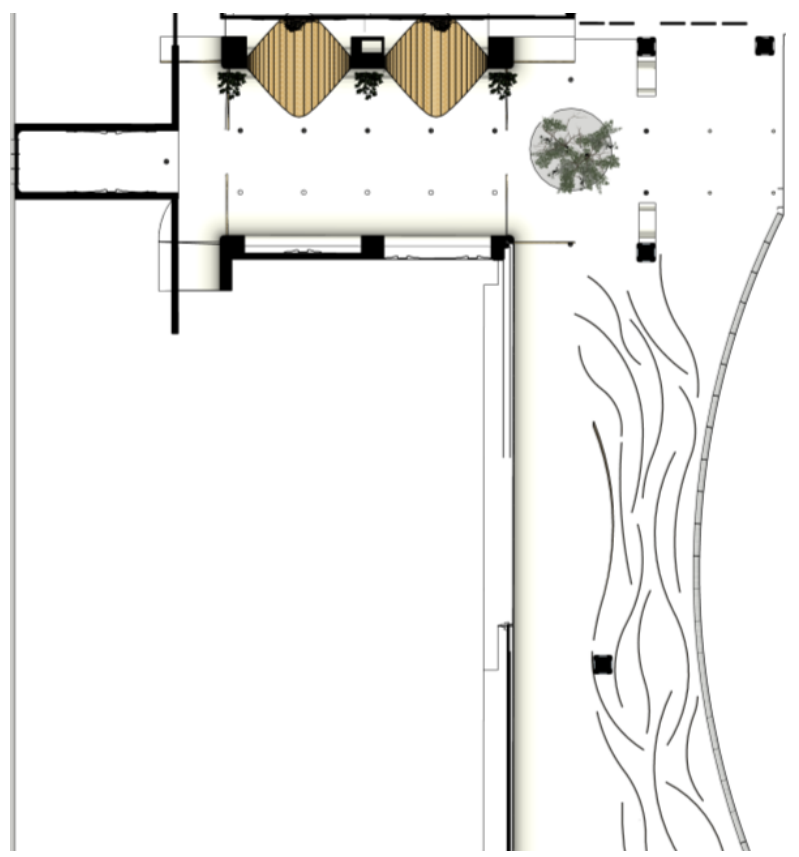

Figure 13 Lobby Ceiling Plan

\subsection{Furniture}

The concept of furniture used in the lobby is shaped like outdoor furniture but with a combination of luxurious and elegant synthetic rattan fabric and woven materials. It still follows the grand Tentrem Hotel lobby's interior concept to bring natural harmony into it.

\subsection{Artwork}

The artwork in the lobby area includes vases and carvings on the walls. There are several ceramic vases in the lobby reception area, which are inspired by Taman Sari as a beautiful and luxurious fragrant garden with plant pots that decorate almost the entire space, especially in the Umbul Binangun area. The ceramic vase in the lobby is quite large, with a broken white color combined with gold accents. The plants used in the lobby area are betel plants, which are native and unique to Indonesia.

Artwork in the form of carving is applied through metal embossed copper plate material in the waiting area and gamelan area. The carvings in this material are made in collaboration with local artists, which are the carvings that tell about Taman Sari and Yogyakarta's history.

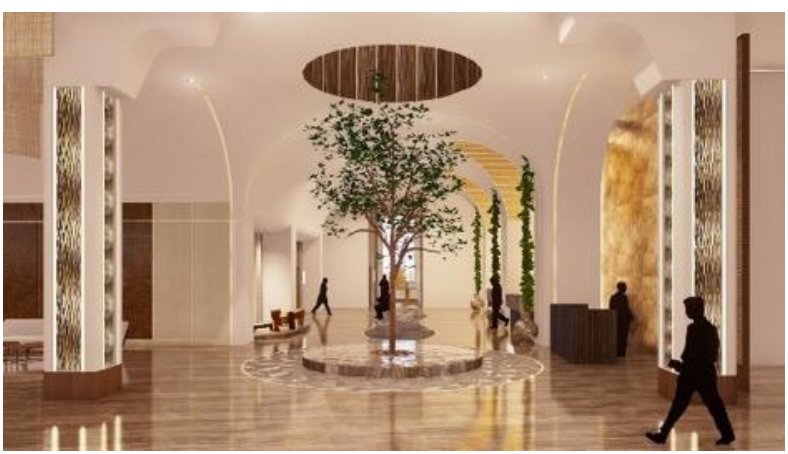

Figure 14 View from the Entrance Lobby

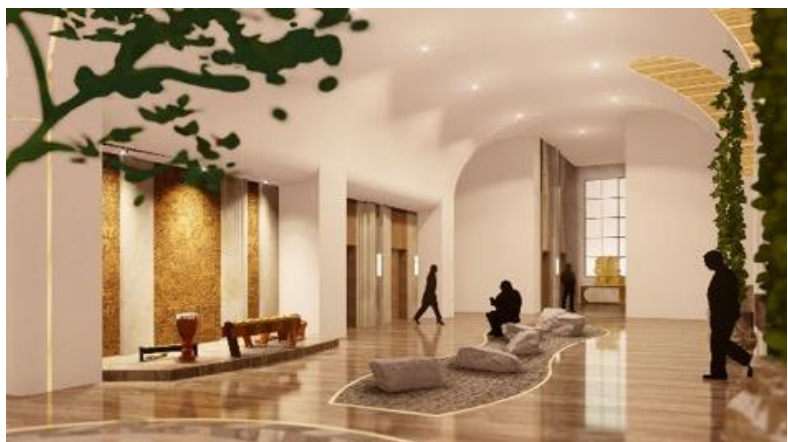

Figure 15 Receptionist Lobby and Elevator Corridor

\section{CONCLUSION}

The inspiration from a historic building, Umbul Binangun Taman Sari, is applied to the interior design of the lobby of Hotel Tentrem Yogyakarta by using the transformation method, which is a method that can be used to create a design with a contemporary style without removing the essence of the object that is used as the inspiration. The transformed elements of Umbul Binangun are then applied to the interior elements of the lobby.

In the hotel lobby, the selection of materials, shapes, and colors in the room-forming elements (floor, lobby, and ceiling) and space-filling elements (furniture and artwork) is essential because it will affect the ambience and image of the hotel. The right combination of materials, shapes, and colors will create a positive message for hotel visitors.

The Lobby of Hotel Tentrem Yogyakarta takes inspiration from the local content of Umbul Binangun Taman Sari. The concept is applied in forming and space-filling elements such as laminated glass flooring, water rippled panels, metal wire mesh, wood panels, ceiling shapes, and color choices dominated by broken white color with a warm ambience. The use of materials, colors, and shapes always pays attention to their aesthetics and functions to provide a harmonious blend under the image and vision, and mission of Hotel Tentrem. 


\section{REFERENCES}

[1] Yoeti, O. A. (2008). Ekonomi Pariwisata: Introduksi, Informasi, dan Implementasi. Jakarta: Kompas.

[2] Keputusan Menteri Pariwisata, Pos dan Telekomunikasi No. KM.37/PW.304/MPPT-86. Peraturan Usaha dan Penggolongan Hotel. 7 Juni 1986. Jakarta.

[3] Marlina, E. (2008). Panduan Perancangan Bangunan Komersial. Yogyakarta: Andi Offset.

[4] Zasmi, A. V. (2018). PRAKTIK PENGEMBANGAN QUALITY OF WORK LIFE HOTEL TENTREM YOGYAKARTA (Studi Kasus Quality of Work Life di Hotel Tentrem Yogyakarta).

[5] Kurniati, R. (2016). Konservasi Tamansari Yogyakarta Pasca Gempa. Ruang, 2(2), 79-95.

[6] Sulistyono, Y. (2016). SISTEM PENAMAAN TEMPAT DI KOMPLEKS TAMANSARI KERATON YOGYAKARTA (KAJIAN LINGUISTIK ANTROPOLOGIS).

[7] Akbar, M. (2013, 12 14). Jejalah Sejarah Istana Air Tamansari Jogjakarta. Retrieved 1 3, 2020, from IndonesianHolic: https://indonesianholic.com/jelajahsejarah-istana-air-tamansari-jogjakarta/

[8] AllIndonesiaTourism. (2017, 4 7). 32 WATER CASTLE YOGYAKARTA ATTRACTIONS - TAMAN SARI COMPLEX. Retrieved 1 3, 2020, from AllIndonesiaTourism: https://allindonesiatourism.com/ attraction/yogyakarta/water-castle-yogyakarta

[9] Lawson, F. (1997). Hotel, Motel and Condominium Design Planning and Maintenance, Architecture. London: Press Ltd.

[10] Chressetianto, A. (2013). Pengaruh Aksesoris dan Elemen Pembentuk Ruang Terhadap Suasana dan Karakter Interior Lobi Hotel Artotel Surabaya. Intra, 1(2).

[11] Kavanaugh, R., \& Ninemeier, J. D. (1982). Supervision in the Hospitality Industry. Orlando: Educational Institute of the American Hotel \& Lodging Association.

[12] Lawson, F. R. (1994). Restaurant planning and design. Cambdrige: Cambridge University Press.

[13] Neufert, E., \& Amril, S. (1989). Data Arsitek Jilid I. Jakarta: Penerbit Erlangga.
[14] Iskandar, I., Athina, N. A., \& Deviliani, R. A. (2013). Fleksibilitas Sistem Elemen Interior Pada Selasar Sunaryo Art Space. Reka Jiva, 1(02).

[15] Jones, J. Christopher. (1972). Design Methods: Seeds of Human Futures. New York: John Willey \& Sons Ltd.

[16] Safitri, Risma Mawar Novia. (2018). Transformasi Arsitektur Monumen Batas Kota dalam Perancangan Mixed-Use Building sebagai Gateway Kota Yogyakarta Bagian Barat di Kawasan Gamping. Universitas Islam Indonesia.

[17] Santosa, A. (2005). Pendekatan Konseptual dalam Proses Perancangan Interior. Dimensi Interior, 3(2).

[18] Syarif, Sudiarty. (2016). Transformasi Arsitektur Buton dan Bajo dalam Desain Resort Masa Kini di Wakatobi. Institut Teknologi Sepuluh November. 